\title{
Incorporating topography-dependent groundwater storage in AWRA-L improves groundwater flux estimation
}

\author{
$\underline{\text { L.J.M. Peeters }}^{\text {a }}{ }^{\text {, R.C. Doble }}{ }^{\text {a }}$, R.S. Crosbie ${ }^{\mathrm{a}}$ and A.I.J.M. van Dijk ${ }^{\text {a }}$ \\ ${ }^{a}$ Water for a Healthy Country National Research Flagship \\ Email: luk.peeters@csiro.au
}

\begin{abstract}
The landscape component of the Australian Water Resources Assessment system, AWRA-L, is a grid-distributed biophysical model designed to simulate water storage in and flows between vegetation, soil, surface water and groundwater for the Australian continent [van Dijk, 2010a].
\end{abstract}

This study addresses three known issues with the representation of groundwater dynamics in version 0.5 of AWRA-L:

1. The saturated area fraction per grid cell, which controls surface runoff, soil and groundwater evaporation, is computed as the ratio of groundwater storage over a reference groundwater storage, rather than a function of groundwater storage and topography.

2. The entire groundwater store is ultimately accessible for evapotranspiration, while in reality only the fraction of the groundwater store in reach of plant roots is accessible.

3. Groundwater discharge to rivers is a function of groundwater storage without taking into account the connection status of the river. Ephemeral streams are therefore not well represented in AWRAL.

These issues are addressed by using topography information in the calculation of saturated area fraction and baseflow. Topographic variability within an AWRA-grid cell is represented by hypsometric curves derived from a 9" Digital Elevation Model. The minimum elevation within the cell is assumed to be equal to the drainage elevation. The DEM data is transformed into potential groundwater storage by multiplying cell ground elevation by effective porosity. The saturated area fraction corresponding to a groundwater storage level is then obtained from hypsometric curves.

By subtracting an extinction depth from the hypsometric curve, the fraction of groundwater storage available for evapotranspiration can be computed. This provides a mechanism for groundwater storage to be lower than the storage corresponding to drainage elevation. Under the assumption that the river system is disconnected or losing in this situation, baseflow to rivers is only computed if storage is greater than the drainage elevation.

Results for a limited number of test locations, representative for a range of Australian conditions, show that the results of the modified model are in better agreement with the conceptual understanding of groundwater dynamics at these locations.

Keywords: AWRA-L; groundwater dynamics, clay content, groundwater storage 


\section{INTRODUCTION}

Numerous studies have highlighted the importance of groundwater dynamics in representing the hydrological cycle in large, continental scale land-surface models [Koster et al., 2000; Fan et al., 2007; Leung et al., 2011]. The inherently slow response time of groundwater dynamics provides a long-term memory of climate forcing, which is especially important for multi-year or decadal drought conditions. Shallow watertables can increase soil moisture and evapotranspiration, while deep water tables can have the opposite effect.

The goal of this paper is to improve the representation of groundwater dynamics in an existing land surface model, the land surface component of the Australian Water Rescource Assesment system (AWRA-L, van Dijk, 2010a). AWRA-L is a grid-distributed biophysical model that simulates water stores and flows in the vegetation, soil and local catchment groundwater systems. In its design the optimal balance was sought between model structure parsimony and the ability to simulate daily streamflow observations for 260 selected, unregulated catchments in Australia [van Dijk, 2010b]. Another major factor in the system design is the availability of reliable data at the continental scale to drive and parameterise the AWRA-L system.

In a comparison of AWRA-L computed long term recharge to groundwater with point recharge estimates from measurements [Crosbie et al., 2010; Peeters et al., 2010], three main issues were identified with regards to groundwater dynamics.

1. The saturated area fraction per grid cell, which controls surface runoff, soil and groundwater evaporation, is computed as the ratio of groundwater storage over a reference groundwater storage, rather than a function of groundwater storage and topography.

2. The entire groundwater store is accessible for evapotranspiration from plants, while in reality only the fraction of the groundwater store in reach of the roots is accessible.

3. Groundwater discharge to rivers is a function of groundwater storage without taking into account the connection status of the river. Ephemeral streams are therefore not well represented in AWRAL.

These three issues are dealt with by introducing subgrid topographic information through the grid cell's hypsometric curve. This allows the saturated area fraction to be a function of topography, to reduce groundwater discharge to zero whenever groundwater storage drops below the storage corresponding to the drainage elevation of the grid cell. In combination with a extinction depth, the topograhic information can be used to limit the groundwater available for plant consumption.

\section{Methods}

\subsection{Conceptual Model}

AWRA-L combines relatively simple, lumped models of catchment water balance and vegetation ecohydrology and phenology. A detailed description of the model structure can be found in van Dijk [2010a]. The model includes partitioning of precipication between interception evaporation and net precipitation. The latter is further partitioned into infiltration, infiltration excess surface runoff and saturation excess runoff. The infiltration flux enters a three layer soil model consisting of a topsoil, shallow soil and deep soil layer (Fig. 1). Water is consumed by soil water evaporation and root water uptake and the remaining flux is routed to the next layer. The water leaving the deep soil layer is considered deep drainage and gets routed to the groundwater store. Water can leave the groundwater store by direct evaporation, capillary rise and discharge to surface water. The sum of these fluxes is the net recharge to groundwater. The surface water store receives water from infiltration excess surface runoff, saturated area runoff and groundwater discharge. Surface water can only leave the model as an input to a river routing model (AWRA-R). The model structure assumes no lateral fluxes between grid cells.

\subsection{Hypsometric Curves}

Fig. 1 illustrates the concept of introducing topography controlled groundwater storage through hypsometric curves. Within an AWRA grid cell the topographically lowest point can be assumed to be the 


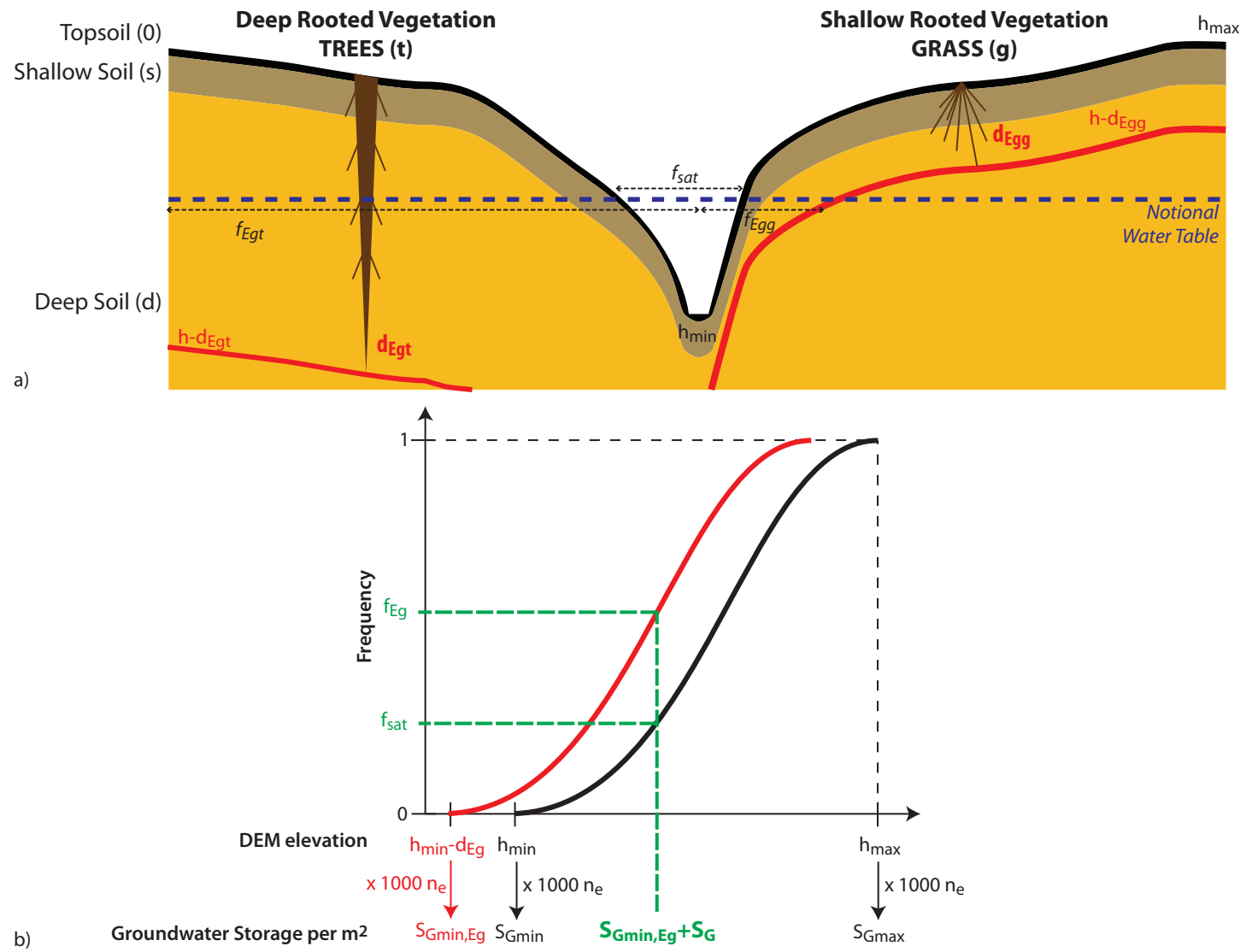

Figure 1. a) AWRA-L conceptual cross-section for a grid cell with $50 \%$ deep rooted vegetation and 50 $\%$ shallow rooted vegetation. b) Elevation hypsometric curves

drainage elevation. The saturated area fraction, $f_{s a t}$, is then defined as the fraction of the grid cell for which the water table is equal to or above topography. Plants will be able to access groundwater through capillary rise, albeit only where the water table is in reach of their roots. This depth is defined as the extinction depth, $d_{E g}$ and the area of the grid cell in which plants can access groundwater is $f_{E g}$.

To calculate both $f_{s a t}$ and $f_{E g}$ hypsometric curves are used. The hypsometric curve is the cumulative distribution of topographic elevation within an AWRA grid cell, based on a finer scale DEM. The topographic elevation data in $m$ are transformed into an equivalent storage volume (per $\mathrm{m}^{2}$ ) in $m m$ according to:

$$
S_{G}=10^{3} n_{e} h
$$

with $h$ topographic elevation (m) and $n_{e}$ effective porosity or specific yield (-). By transforming the hypsometric data into storage volumes, $f_{s a t}$ and $f_{E g}$ can be obtained directly for any given groundwater storage volume $S_{G}$ (Fig. 1b).

The datum for groundwater storage is set equal to $S_{G \min , E g}$, the storage corresponding to the situation where all groundwater accessible to plants is consumed. The water table used in this concept is a notional water table, that is a single value for the grid cell, calculated as the height above the datum corresponding to the groundwater storage.

The newly defined $f_{\text {sat }}$ is used subsequently in the calculation of runoff and groundwater evaporation. The latter implies that groundwater evaporation is limited to the fraction of the grid cell for which the groundwater table is equal to topography.

The area fraction accessible for groundwater evapotranspiration, through capillary rise to the root zone is determined by $f_{E g}$. This variable is used in the expression for capillary rise, $Y$, which provides the mechanism to transport water from groundwater to the soil layers and thus making it accessible for uptake by plants: 


$$
\begin{aligned}
f_{Y} & =1-\frac{1}{1+\exp \left(-100\left(w_{z}-w_{z l i m U}\right)\right)} \\
Y & =\min \left(f_{E g} U, f_{Y} f_{E g} S_{G}\right)
\end{aligned}
$$

where $w_{z}$ is the relative soil water content, $w_{z l i m}$ is the relative soil water content at which plant water uptake becomes limiting and $U$ is the plant water uptake. The fraction $Y$ is a modified logistic function to ensure that capillary rise only starts to occur as soon as the relative water content drops to the relative water content for which plant water uptake is limited. Water in the soil layer is then replenished by the fraction of water from groundwater storage that is accessible for groundwater evapotranspiration. The capillary rise is limited to the evaporative demand, the root water uptake, $U$ multiplied with $f_{E g}$ so that only the fraction of root water uptake within reach of the root zone can be compensated by capillary rise.

The final change to the code is in the implementation of a baseflow threshold based on the hypsometric curves. As soon as the volume of water drops below the storage level corresponding to drainage elevation, baseflow reduces to zero:

$$
Q_{G}=\left(1-\exp \left(-K_{G}\right)\right) \max \left(0,\left(S_{G}-\left(S_{G m i n}-S_{G m i n, E g}\right)\right)\right)
$$

where $K_{G}$ is an emperically derived drainage coefficient [van Dijk, 2010a].

The datum for groundwater storage is set so $S_{G}=0$ for the storage equivalent to $h-\max \left(d_{E g t}, d_{E g g}\right)$. As only the volume of water above the drainage elevation can contribute to baseflow, the available storage volume for baseflow becomes $S_{G}-\left(S_{G m i n}-S_{G m i n, E g}\right)$.

\section{Results}

\subsection{Test Locations}

To evaluate the changes to the model code, $250.05^{\circ}$ AWRA-L grid cells are selected in Australia, representing diverse climatic and topographic conditions. The model is run for these 25 locations using historic data over a 120 year period, from $1 / 1 / 1890$ to $1 / 1 / 2011$.

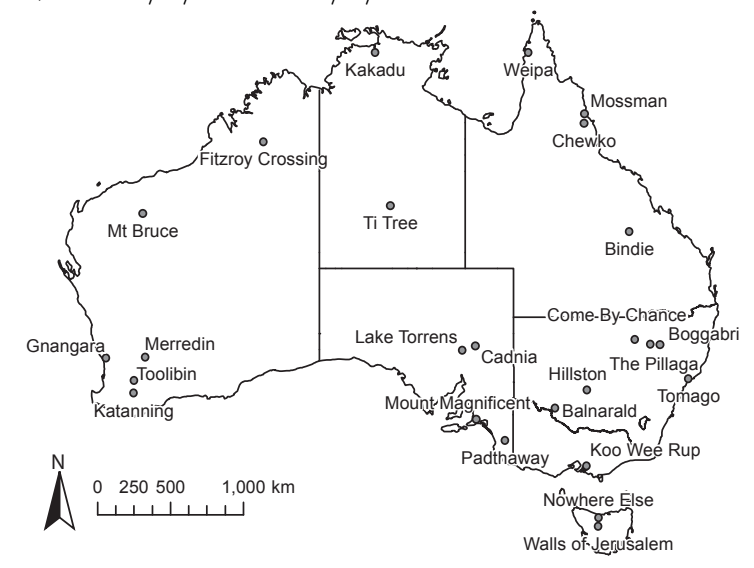

Figure 2. Test Locations

In the selection of these locations an attempt is made to encompass as much as possible the variability in climate, topography and soil type that occurs in Australia (Fig. 2). The locations thus vary from very flat, arid areas, such as Lake Torrens, to temperate, mountainous areas such as Walls Of Jerusalem and tropical, flat areas such as Kakadu and Weipa. Other factors that played a role in the selection of test locations was the occurrence of extreme groundwater dynamics, such as Gnangara and Tomago, where a flat topography in combination with a very sandy soil ensures very high net groundwater recharge or Koo Wee Rup, where a shallow water table together with a flat topography gives rise to a large groundwater evapotranspiration rate. Finally, a number of locations are included to be representative for important 
groundwater management zones, such as the Namoi (Come By Chance) and Murrumbidgee catchments (Balranald), the Padthaway irrigation area and the wheat belt in Western Australia (Katanning).

The most important new preprocessing step for the modified AWRA-code is the calculation of hypsometric curves. The hypsometric curves are based on a 9" DEM [Geoscience Australia, 2009]. For each location a subset of percentiles of the $9 s$ DEM was extracted corresponding to the extent of the AWRA-L grid cell in which the point was situated.

Because a reliable nationwide dataset is not available, porosity was chosen to be uniform for Australia at a value of $15 \%$. The extinction depth for trees $\left(d_{E g t}\right)$ and grass $\left(d_{E g g}\right)$ was set to $6 m$ and $2 m$ respectively, while soil depth was set to $2 \mathrm{~m}$ for shallow soil and $6 \mathrm{~m}$ for deep soil. All sites are assumed to have $50 \%$ grass cover and $50 \%$ tree cover. The reference minimal groundwater storage level was set to $0 \mathrm{~mm}$, which implies that $S_{G \min }$ is equal to $900 \mathrm{~mm}$.

Two model runs are carried out, one using the original AWRA-L code, referred to as AWRA-Lv0.5 and one with the modified code, referred to as AWRA-Lv0.6. The next section highlights some of the salient features of the changes in AWRA-L simulated groundwater dynamics.

\subsection{Groundwater Flux}
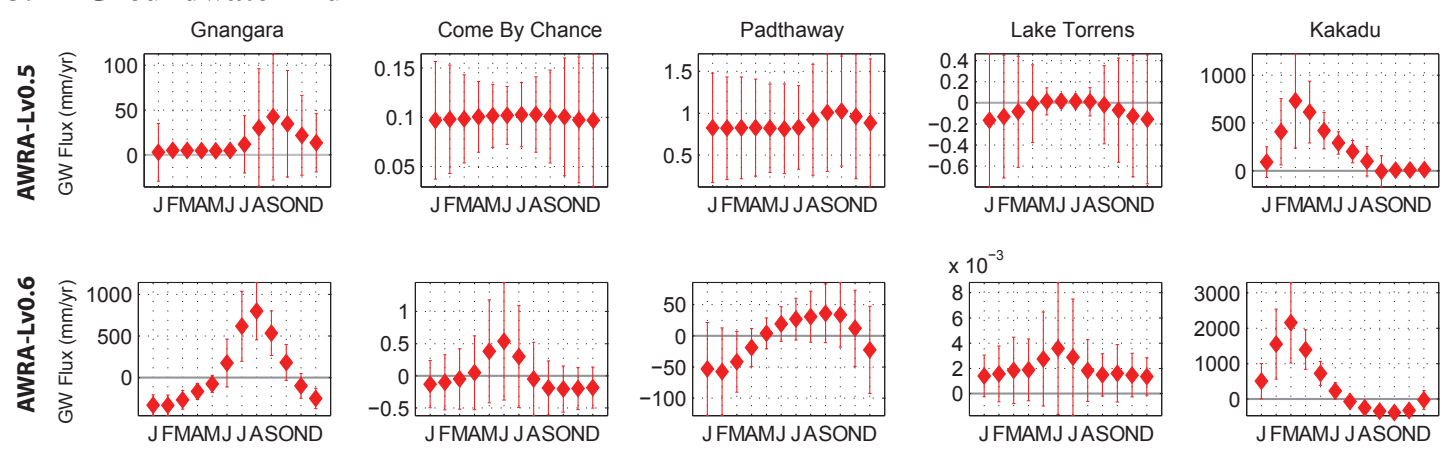

Figure 3. Net groundwater recharge

To illustrate the effect of the changes on the computed groundwater flux, Fig. 3 shows the monthly average net groundwater recharge for selected locations for both model runs. In Gnangara, reformulation of capillary rise leads to negative summer groundwater flux, while the groundwater storage is replenished in winter. A similar effect can be observed in Come By Chance and in Padthaway. Due to an artifact in the calculation of saturated area in AWRA-Lv0.5, groundwater evaporation is very high for Lake Torrens. The updated version shows limited seasonality for near zero recharge values. Kakadu displays the temporal dynamics of the tropics, with very high rainfall during the wet season and no or negative recharge during the dry season. For this location as well, the changes lead to higher variability and allow for negative net recharge, i.e. diffuse groundwater discharge.

Time series of groundwater storage, deep drainage, capillary rise, groundwater evaporation and net recharge of Koo Wee Rup and Balranald (Fig. 4) are used here to provide more detail on some of the most prominent conceptual improvements to the model structure. The deep drainage estimates show different patterns as both the parameterisation and conceptualisation of the unsaturated zone is altered. The capillary rise $(Y)$ in AWRA-Lv0.5 is a function of groundwater storage and the relative water content in the deep soil layer. In Balranald the capillary rise therefore is almost equal to the groundwater store. The modified conceptualisation of capillary rise (eq. 3) in AWRA-Lv0.6 provides two constraints to the capillary rise; the fraction of $S_{G}$ accessible to vegetation $\left(f_{E g}\right)$ and the evaporative demand of vegetation $(U)$. The latter constraint dominates the $Y$ time series of Koo Wee Rup. For Balranald the combined effect of both constraints is apparent. The overall trend is a fraction of groundwater storage, thus dominated by the $f_{E g}$ constraint. Departures from this trend arise if evaporative demand is low.

Groundwater evaporation, $E_{g}$, is calculated in both model versions as:

$$
E_{g}=f_{\text {sat }} F_{\text {sEmax }}\left(E_{0}-E_{T}\right)
$$

If the $f_{\text {sat }}$ parameter is overestimated, $E_{g}$ will be too high and the temporal signal of $\left(E_{0}-E_{T}\right)$ will persist in the groundwater storage and therefore in the capillary rise term. This is most apparent for 

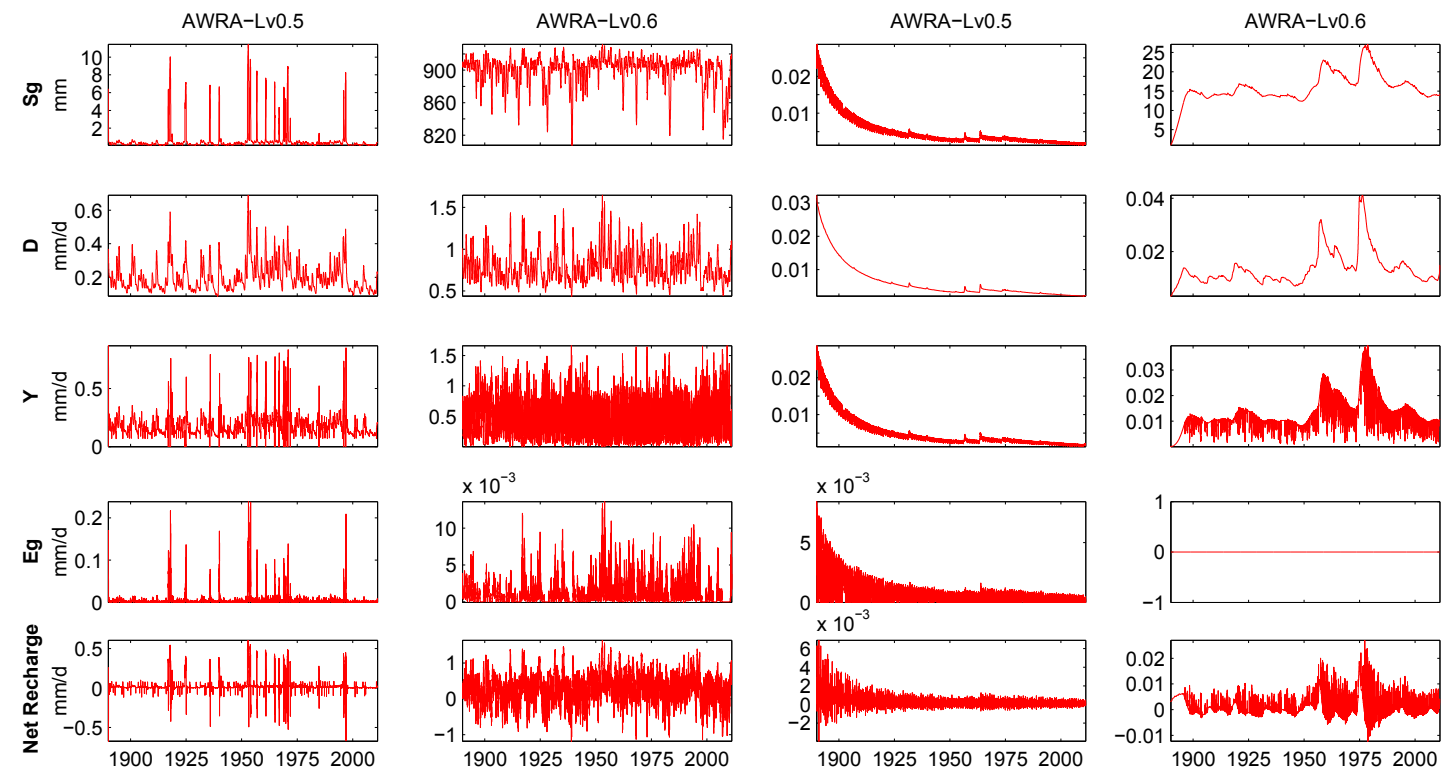

Figure 4. Groundwater storage, $S_{G}$, deep drainage, $D$, capillary rise, $Y$, groundwater evaporation, $E_{g}$, and net groundwater recharge for Koo Wee Rup and Balranald

Balranald, where the $E_{g}$ time series of AWRA-Lv0.5 has a very strong temporal variation, while the overal trend is a decrease as the groundwater store decreases. In AWRA-Lv0.6 $E_{g}$ is 0 as the groundwater storage is below the level equivalent to the drainage elevation. In Koo Wee Rup, a small fraction of the grid cell is saturated with groundwater and $E_{g}$ occurs.

\subsection{Total Flow and Baseflow}
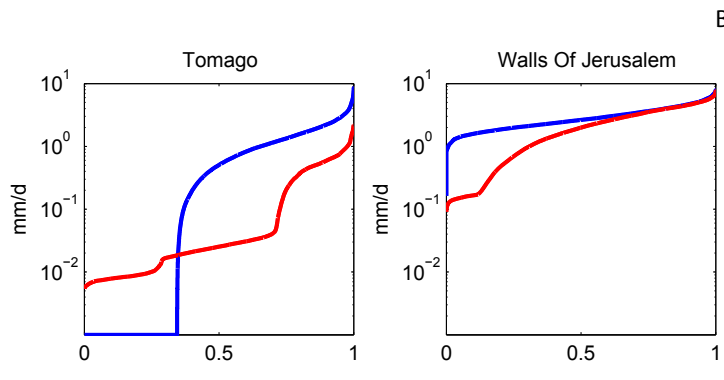

Baseflow
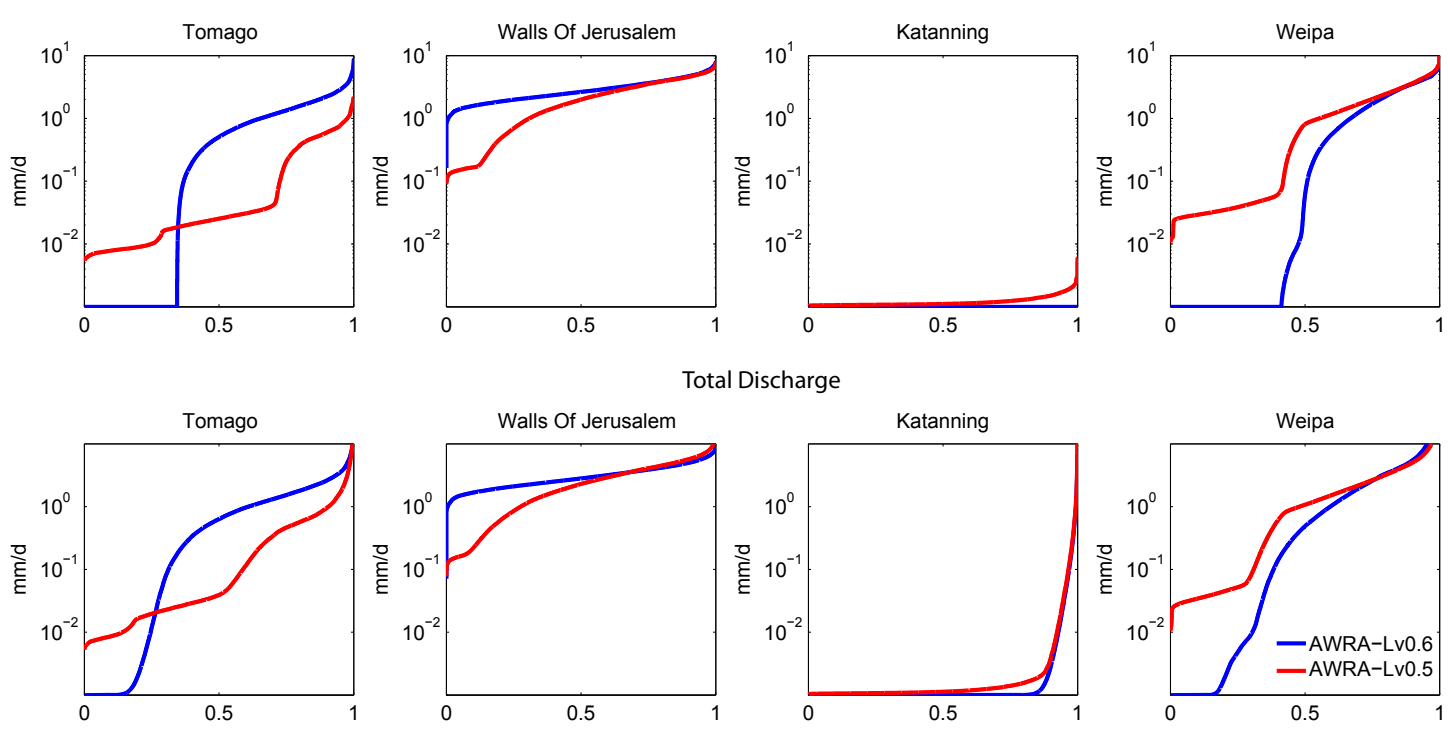

Figure 5. Time series of groundwater storage and flow duration curves for base flow and total discharge

The effects of introducing a baseflow threshold are illustrated in Fig. 5 for Tomago, Walls Of Jerusalem, Katanning and Weipa. The most striking change is the baseflow for Katanning, which is reduced to zero in AWRA-Lv0.6. This obviously affects the low flows of total discharge. The high flows however hardly change. This can be observed for all locations shown; the modifications are mostly limited the low flows. The exception is Tomago, where the changes in $f_{\text {sat }}$ are substantial enough to profoundly alter the 
shape of the flow duration curve. In Weipa the tropical seasonality becomes apparent, with no baseflow and limited total flow in the dry season and high discharge during the wet. The flow duration curves of base flow and total flow in Walls Of Jerusalem are S-shaped when log-transformed for the AWRA-Lv0.6 solution while the AWRA-Lv0.5 solution has a step-change in the low flow section.

\section{Conclusions}

The goal of modifying the existing AWRA-L script was to improve the representation of groundwater dynamics, especially the calculation of net groundwater recharge and simulation of ephemeral streams.

These goals are achieved by introducing topographic information through hypsometric curves for every grid cell.

The modified code is tested in 25 locations representing a variety of Australian climatic conditions, topography and soil types. The results indicate that the above mentioned processes are now part of the dynamic behaviour of the water balance terms simulated with the modified code and are in agreement with the conceptual understanding of groundwater flow dynamics at the test locations. Further research will focus on calibrating and validating the model against stream flow and recharge observations.

\section{ACKNOWLEDGMENTS}

This work is part of the water information research and development alliance between CSIROs Water for a Healthy Country Flagship and the Bureau of Meteorology.

\section{REFERENCES}

Crosbie, R. S., I. D. Jolly, F. W. Leaney, and C. Petheram (2010). Can the dataset of field based recharge estimates in australia be used to predict recharge in data-poor areas? Hydrology and Earth System Sciences 14(10), 2023-2038.

Fan, Y., G. Miguez-Macho, C. P. Weaver, R. Walko, and A. Robock (2007, May). Incorporating water table dynamics in climate modeling: 1 . water table observations and equilibrium water table simulations. Journal of Geophysical Research-atmospheres 112(D10), D10125.

Geoscience Australia, . (2009). Geodata 9 second digital elevation model (dem-9s) version 3. Technical report, Geoscience Australia.

Koster, R. D., M. J. Suarez, A. Ducharne, M. Stieglitz, and P. Kumar (2000). A catchment-based approach to modeling land surface processes in a general circulation model 1. model structure. J. Geophys. Res. 105(D20), 24809-24822.

Leung, L. R., M. Y. Huang, Y. Qian, and X. Liang (2011, January). Climate-soil-vegetation control on groundwater table dynamics and its feedbacks in a climate model. Climate Dynamics 36(1-2), 57-81.

Peeters, L., R. Crosbie, and A. van Dijk (2010). Evaluation of awra-1 net recharge: Comparison to measured recharge \& waves results. Technical report, CSIRO: Water for a Healthy Country National Research Flagship.

van Dijk, A. I. J. M. (2010a). The australian water resources assessment system. technical report 3. landscape model (version 0.5) technical description. Technical report, CSIRO: Water for a Healthy Country National Research Flagship.

van Dijk, A. I. J. M. (2010b). Selection of an appropriately simple storm runoff model. Hydrology and Earth System Sciences 14(3), 447-458. 